\title{
INFÂNCIA, VANGUARDA E LITERATURA AFRO- ANTILHANA EM LUIS PALÉS MATOS
}

Alejandra Judith Josiowicz

Resumo: $O$ artigo propõe uma análise da cena da infância em uma seleção dos escritos do poeta porto-riquenho Luis Palés Matos (18981959) através da relação com a cultura afro-antilhana. Examino a infância na cultura afro-antilhana em dois níveis diferentes: no nível da forma estética - na experimentação com a oralidade infantil -, e no nível das representações sociais, culturais e étnico-raciais, da herança africana nas Antilhas. Esses dois níveis da cena infância apontam para o projeto de transformar a relação entre o discurso estético e a coletividade por meio da criação, no marco do Porto Rico moderno, de uma nova compreensão da cultura, que aponte ao questionamento da versão hegemônica da identidade nacional como puramente hispânica e branca, e assinale a relevância da cultura afro-antilhana para pensar a língua, a música, a religião, o mito e a subjetividade em Palés Matos.

Palavras-chave: Luis Palés Matos. Poesia afro-antilhana. Infância. Vanguarda. Literatura caribenha.

Resumen: El artículo propone un análisis de la escena de la infancia en una selección de textos del poeta puertoriqueno Luis Palés Matos a través de la relación con la cultura afroantillana. Examino la infancia en la cultura afroantillana en dos niveles diferentes: el de la forma estética, en la experimentación con la oralidad infantil, y en el nivel de las representaciones sociales, culturales e étnico-raciales, de la herencia africana en las Antillas. Esos dos niveles de la escena de la infancia apuntan al proyecto de transformar la relación entre el discurso estético y la colectividad por medio de la creación, en el marco del Puerto Rico moderno, de una nueva comprensión de la cultura, que apunte al cuestionamiento de la versión hegemónica de la identidad nacional como puramente hispánica y blanca, y señale la relevancia de la cultura afroantillana para pensar el lenguaje, la música, la religión, el mito y la subjetividad en Palés Matos.

Palabras clave: Luis Palés Matos. Poesía afroantillana. Infancia. Vanguardia. Literatura Caribeña. 
Este trabalho analisa a cena da infância na cultura afroantilhana em Luis Palés Matos (1898-1959). Partindo de uma seleção de poesias e prosas escritos por Palés Matos, exploramos o modo como a infância na sua obra aponta para a importância da tradição cultural africana das Antilhas. Analiso a infância em dois níveis: por um lado, no nível da forma estética - na experimentação com a oralidade infantil, em um estado prévio à formação do simbólico -; por outro, no nível da herança africana e sua relação com questões sociais e étnicoraciais próprias da cultura afro-antilhana. Esses dois níveis da figuração da infância - que são, de fato, inseparáveis em Palés Matos - configuram modos de articular o discurso estético e a coletividade por meio da criação de uma cultura afro-antilhana nova, própria do Porto Rico moderno, que desse conta dos conflitos, das resistências e da heterogeneidade cultural que caracterizam essa herança. Desse modo, a infância aponta ao questionamento da versão hegemônica da identidade nacional como puramente hispânica e branca, e assinala a relevância da cultura afro-antilhana para pensar a língua, a música, a religião, o mito e a subjetividade em Palés Matos.

\section{Trajetória e obra do poeta afro-antilhano}

Luis Palés Matos é para muitos o máximo poeta portoriquenho. Nasceu em 1898 em Guayama, uma pequena 
cidade de população predominantemente africana, em uma família de baixos recursos econômicos, segundo filho de Vicente Palés Anés, poeta e professor de escola, e Consuelo Matos Vicil, poetisa (JOSIOWICZ, 2017). No mesmo ano de seu nascimento, Porto Rico atravessou a guerra hispanocubano-norte-americana e teve lugar a invasão de Porto Rico pelo exército norte-americano, como resultado do qual a ilha passou a ser dependência colonial dos Estados Unidos. Após da morte de seu pai, deveu abandonar seus estudos e começou uma vida de precariedade laboral e econômica que só seria atenuada em 1944, quando foi nomeado poeta residente na Universidade de Porto Rico (JOSIOWICZ, 2017). Ao longo de sua vida, além de colaborar em periódicos e revistas locais e nacionais como poeta, cronista, e crítico cultural, trabalhou como professor de escola, bibliotecário e funcionário em vários órgãos públicos. Formou com José de Diego Padró o diepalismo, um dos primeiros movimentos de vanguarda em Porto Rico. De fato, Palés Matos é reconhecido como um dos iniciadores da vanguarda estética em Porto Rico e o pioneiro do chamado negrismo nas Antilhas hispânicas, introduzindo temas e ritmos afro-antilhanos na prosa e na poesia. Participou em uma polêmica entre vários intelectuais porto-riquenhos, na qual rejeitou a imagem da identidade 
nacional porto-riquenha como exclusivamente branca e hispânica e defendeu a importância do elemento cultural africano para pensar a vida cultural do Caribe, a música e a dança, a vida religiosa, os esportes e inclusive a política. Em 1937, publicou a primeira edição do livro de poesias Tuntún de pasa y grifería, o qual escreveu e rescreveu entre 1925 e 1952. Publicou capítulos de sua ficção autobiográfica Litoral. Reseña de una vida inútil em periódicos e revistas de Porto Rico. Em 1957, apareceu a primeira antologia de sua Poesía (1915-1956), que ele mesmo selecionou e revisou. Faleceu de um ataque cardíaco em Santurce, Porto Rico, aos 61 anos. Sua poesia foi celebrada e reconhecida pela crítica e circulou oralmente, reconhecida no Caribe, na Espanha, na América Latina e nos Estados Unidos (JOSIOWICZ, 2016).

Para entender a obra de Luis Palés Matos, devemos considerar o fato de que a oralidade e o diálogo com as tradições culturais afro-antilhanas cumpriram um papel fundamental na circulação e consagração de seus textos. Dadas as características da indústria do livro e das instituições culturais porto-riquenhas na primeira metade do século vinte, a consagração não pode ser pensada no âmbito da academia ou do mercado literário, mas sim no mundo da boemia, os cafés, a publicação em revistas 
locais, de frequência e continuidade variáveis, e a imprensa nacional (LÓPEZ-BARALT, 1995, p. 5). Palés Matos foi crítico da falta de institucionalização do meio intelectual portoriquenho, que marcou sua trajetória como escritor e sua concepção pessimista do papel do escritor e do poeta em Porto Rico. Queixava-se do isolamento, a desvalorização das tradições culturais locais e nacionais, o caráter colonial do meio e a escassez de estímulos intelectuais (PALÉS MATOS, 1984, p. 289).

Nesse meio cultural fragmentado, sua poesia circulou em forma oral, graças a recitadores locais e internacionais, e no meio jornalístico, em periódicos e revistas. De fato, suas produções poéticas e narrativas foram inicialmente veiculadas em revistas e jornais regionais e nacionais de Porto Rico e só posteriormente publicadas em forma de livro. Outros intelectuais interessados nas tradições de origem afro-hispânica o conheceram e dialogaram com ele, como Federico García Lorca - que costumava recitar de cor alguns poemas negristas de Palés -, o cubano Nicolás Guillén, o jamaicano/norte-americano Claude McKay e o antropólogo Fernando Ortiz (JOSIOWICZ, 2016). 


\section{A infância como experimentação estética e diálogo com a cultura afro-antilhana}

Este artigo propõe considerar a cena da infância ${ }^{1}$ na cultura afro-antilhana, tal como aparece em Palés Matos, como condensação de uma série de preocupações estéticas, ao mesmo tempo que de visibilização de questões étnicoraciais. No primeiro nível, o da forma estética, a importância da infância pode ser detectada no diálogo de Palés Matos com as vanguardas estéticas hispano-americanas e europeias. Os vanguardistas hispano-americanos seguiram de perto a exploração da infância por parte das vanguardas europeias - seja pelo Dadaísmo, pelo Surrealismo francês, pelo Expressionismo alemão, pelo Cubismo, pela arte naif e pelo primitivismo - e fizeram da criança um mecanismo de experimentação iconoclasta, com o dissonante e o inconsciente. $^{2}$ Os vanguardistas hispano-americanos, além disso, seguiram de perto o projeto psicanalítico de exploração do inconsciente.

Nas artes plásticas, as vanguardas europeias - o art brut, o infantilismo de Picasso, Kandinsky e outros - fizeram

\footnotetext{
1 Uso "cenas" em um sentido similar ao desenvolvido por Jacques Rancière (2013): a cena inscreveria o evento estético em uma constelação variável de modos de percepção, afetos e modos de interpretação, e constituiria a comunidade sensível e intelectual que torna possível essas relações (2013, p. 11).

2 Para a figuração da infância em outros escritores das vanguardas hispano-americanas e brasileiras, como César Vallejo e Mário de Andrade, ver Josiowicz, 2013, 2015 e 2019.
} 
uso do traço pueril da criança como linguagem mítica, carente de artificio, que orientaram a uma quebra com a tradição (CAROTO, 2004; WITTMAN, 2004; IANONE, 2004). O surrealismo francês teorizou o lugar da criança como exploração de um acesso direto ao inconsciente (KRAUSS, 1988; FOSTER, 1993). Através de procedimentos como o automatismo psíquico ou a associação automática, o artista surrealista seria capaz de acessar o estado de plenitude e unidade originária, idílica e liberatória em que viveria a criança (FOSTER, 1993). O artista de vanguarda se identifica com a criança que emerge recém-nascida, desde um grau zero da criação artística, sem modelo nem referente além de si mesma (KRAUSS, 1988). No futurismo italiano, a criança carrega um caráter organicista, uma ideia originária do sujeito, como garantia de originalidade e quebra da tradição (KRAUSS, 1988, p. 157). Por seu lado, o surrealismo representa a infância através de uma série de fantasias intrauterinas primárias, de intimidade corporal e unidade psíquica com o corpo da mãe (FOSTER, 1993). Essa visão da infância, como o teórico da arte Hal Foster já salientou, aponta para a leitura ambígua que o surrealismo realiza do inconsciente psicanalítico como campo reconciliado de associações, menos baseado em conteúdos infantis escuros e perversos à la Freud e menos um produto da repressão primária (FOSTER, 1993, p. 1-17). 
As vanguardas hispano-americanas dialogam, mas também tomam distância da cena da infância nas vanguardas europeias, dado que prescindem de qualquer categoria orgânica ou vitalista do eu e questionam qualquer imagem compensatória ou idílica da infância na sua leitura da psicanálise freudiana. Os vanguardistas hispano-americanos projetam a exploração do subsolo mítico da infância com o objetivo de descobrir os labirintos não só da memória, mas também os arquétipos do amor, a morte, a angústia, o medo e a luta, atravessando o território do sonho, o delírio, a hiper consciência e a alienação (BOSI, 2002, p. 28). Trata-se da investigação da criança em relação com as tradições populares, orais, rituais e míticas, e como estratégia de transgressão estética. A criança das vanguardas hispano-americanas se rebela diante dos cânones literários e das normas gramaticais, recupera a coloquialidade e as tradições africanas e questiona qualquer visão unívoca da subjetividade (JOSIOWICZ, 2013).

No segundo nível, a infância em Palés Matos aponta para uma série de debates sociais, políticos e étnico-raciais, sobre questões como a heterogeneidade social e racial nas Antilhas. Em Porto Rico, o Partido Popular Democrático na década de 1940 fez do camponês, o jíbaro, associado à herança branca e hispânica, uma imagem mitológica e 
política importante para o discurso populista (QUINTERO RIVERA, 2000; 2005). O jíbaro tornou-se símbolo da nacionalidade desde a década de 1930, através de um discurso que dava ênfase ao seu caráter hispânico e branco, e marginalizava a herança africana, considerada cultural e racialmente inferior. O ideal hispânico e branco do jíbaro é sintomático das preocupações com a heterogeneidade étnico-racial da população entre a intelectualidade portoriquenha, e diz respeito à busca de independência cultural em relação à metrópole norte-americana. A imagem do jíbaro assinala o desconforto dos intelectuais portoriquenhos com a política imperialista e intervencionista dos Estados Unidos, com a monocultura de exploração do açúcar que asfixiava a economia porto-riquenha e a influência, nos meios de comunicação, da cultura anglosaxã. Foi em resposta à imagem hegemônica do jíbaro que um grupo de poetas, antropólogos, historiadores, políticos e escritores caribenhos recuperaram a importância da herança africana no projeto nacional porto-riquenho.

Esses intelectuais, sobretudo poetas, antropólogos e escritores foram impulsores e criadores dos movimentos afro-antilhanistas ou negristas e, ajudados pelo auge de gêneros da música e da cultura popular ligados às tradições 
afro-caribenhas, desenvolveram nesses anos um novo olhar em torno da herança africana. O movimento negrista nasce nas Antilhas com o propósito de conscientizar sobre a importância da cultura africana, assim como dos direitos e a identidade das populações africanas no Caribe. Uma das figuras mais importantes nesse marco foi o antropólogo Fernando Ortiz, nascido em 1888, um dos primeiros a investigar a língua, a religião, as tradições e a cultura afrocubana (MYERS, 2015). Em sua conferência "Ni racismos ni xenofobias" (1929), Ortiz se opõe aos preconceitos raciais e argumenta que a cultura cubana estaria integrada, como parte de uma mesma unidade, por sujeitos de raças e culturas distintas: saxões, hispanos, italianos, mestiços e africanos. Desse modo, valoriza a cultura africana, em lugar de igualdade com os outros componentes da cultura cubana.

$\mathrm{Na}$ literatura, o movimento da negritude involucrou a uma série de escritores e artistas que introduziram a cultura de origem africana na América Hispânica, renovando radicalmente a poesia através da inclusão da tradição popular oral afro-caribenha. Junto a Palés Matos, o poeta e intelectual cubano Nicolás Guillén, nascido em 1902, foi também fundador da poesia negrista. Guillén criou a poesia afronegrista em Cuba: em seu livro Motivos de son (1930), 
por exemplo, recria a fala dos bairros pobres da Havana, a oralidade e o ritmo musical e sensual do som, baile típico de Cuba. Já no seu livro Songoro Cosongo (1931), Guillén confere relevância a questões raciais e sociais e à reivindicação dos direitos das populações afro-antilhanas no Caribe. No prólogo ao livro, Guillén afirma que o espírito de Cuba é mestiço e propõe um poeta mulato e uma poesia mulata para um país também mulato.

O contato de Palés Matos com a obra de intelectuais envolvidos na valorização da cultura afro-antilhana, como Fernando Ortiz, Nicolás Guillén, Claude McKay e outros, o guia na busca por questionar a representação hispânica, branca e etnocêntrica da cultura popular porto-riquenha por meio da valorização da multiplicidade étnico-racial Antilhas, da celebração do componente cultural afroantilhano do arquipélago e de um questionamento do racismo e do eurocentrismo (DÍAZ QUIÑONES, 2012). Palés Matos considerava que as diferentes ilhas do Caribe formavam uma unidade cultural, e que o escritor devia dar conta da complexidade desse substrato cultural, superando a exclusividade do hispânico e explorando as outras heranças presentes. Desse modo, buscou fugir do etnocentrismo e do europeísmo através da 
valorização do africano, compreendendo a diversidade das tradições culturais do arquipélago. $O$ que une as Antilhas é justamente a condição colonial e pós-colonial, e a influência inegável do industrialismo norte-americano (PALÉS MATOS, 1984, p. 238). Afirma em uma entrevista publicada em 1932 no jornal El Mundo, baseado em San Juan: "Físicamente, las Antillas constituyen también una unidad [...]. Económicamente, girando como giran en la órbita del industrialismo norteamericano, corren iguales contingencias y hasta análogo destino colonial" (PALÉS MATOS, 1984, p. 238). Trata-se de inaugurar uma nova perspectiva para a cultura das Antilhas, capaz de quebrar com o localismo estreito, mas também com o hispanismo eurocêntrico e o imperialismo universalista.

Na mesma entrevista, Palés reforça a importância da inclusão do componente africano e mulato na reflexão sobre a cultura antilhana, tomado como parte fundamental dela. Afirma:

Una poesía antillana que excluya ese poderoso elemento [el negro] me parece casi imposible. El negro vive física y espiritualmente con nosotros y sus características, tamizadas en el mulato, influyen de modo evidente en todas las manifestaciones de nuestra vida popular. (PALÉS MATOS, 1984, p. 299-300) 
E adiciona:

Refiriéndose al yanqui, Jung sostiene que el americano es un europeo con maneras de negro y alma de indio. Soslayando este concepto hacia nosotros, yo diría que el antillano es un español con maneras de mulato y alma de negro. Esta definición sublevará, indudablemente, a muchos temperamentos. Pero ni el español ni el negro protestarán. (PALÉS MATOS, 1984, p. 300)

Palés Matos transgrede a ideologia oficial de modo irreverente e satírico, afirmando que a cultura antilhana seria fruto da multiplicidade de influências contraditórias, das tensões e das ambivalências entre a herança hispânica, a africana e a mestiça. Para tanto, parte do conceito de transculturação, cunhado por Fernando Ortiz, assim como do inconsciente coletivo de Carl Gustav Jung, para argumentar que as culturas dominadas poderiam "infiltrar paulatinamente" as culturas dominantes de modo tal que Ihes imprimam seu próprio espírito, "modificándolas con tan corrosiva eficacia que den pábulo al nacimiento de una cultura nueva" (PALÉS MATOS, 1984, p. 239). Palés Matos argumenta a favor de um conceito fluido e dinâmico de cultura, ao mesmo tempo individual e coletivo, subconsciente e social, que implica a transformação tanto do elemento hispânico como do africano no contato 
intercultural, do qual resultaria a constituição de uma nova cultura antilhana.

\section{A vanguarda afro-antilhana de Luis Palés Matos}

Luis Palés Matos foi pioneiro da investigação da cultura afro-antilhana como central para a cultura diaspórica do Caribe: sua obra dialoga com a cultura popular e o rito, como também com a coloquialidade vernácula das ruas, a partir da exploração da herança cultural africana e mestiça nas Antilhas. Para tanto, valeu-se do diálogo com diversas correntes estéticas, a partir das quais tentou construir novas relações entre arte, infância e cultura afro-antilhana. Conheceu a tradição poética clássica, a poesia moderna e as vanguardas, através de autores tão díspares como Luis de Góngora, Federico García Lorca, Rubén Darío, Leopoldo Lugones, Julio Herrera y Reissig, Nicolás Guillén, Claude McKay e muitos outros. Na década de 1920, Palés Matos entrou em contato com a estética das vanguardas europeias, sobretudo com o dadaísmo, e descobriu a psicanálise através dos textos de Carl Gustav Jung, Sigmund Freud e Alfred Adler (LUNA, 2001, p. 120). Junto ao poeta também porto-riquenho José I. de Diego Padró, Palés Matos publicou, em 1921, o poema "Orquestación Diepálica". Trata-se de experimento no objetivismo sintético, marcado pelas ressonâncias 
dadaístas e pelo uso da onomatopeia, isso é, pelo interesse na materialidade sonora do poético.

Em seu artigo "O Dadaísmo" de 1922 aparecido no jornal La Semana, de Porto Rico, observa o infantilismo humorístico, cândido e iconoclasta do dadaísmo europeu e aponta para a relevância da infância nessa estética:

Detrás de una máscara de irresponsabilidad y humor infantil, dentro de esta buscada puerilidad de acción y expresión se esconde un espíritu grave y monstruoso [...]. El dadaísmo es un movimiento más serio y grave de lo que parece a primera vista. En su fondo lleva escondido un tábano siniestro y a través de esa risa iconoclasta y de esas explosiones infantiles, de aparente candor e inocencia, se filtra una agria virilidad, un dolor verdaderamente patético, un drama profundamente universal: el grande $y$ ancho drama de la caída de todo el sistema dominante. (PALÉS MATOS, 1984, p. 214)

Palés Matos observa a "máscara de humor infantil" dos experimentos aparentemente pueris do dadaísmo, suas "explosões infantis, de aparente candor e inocência", isso é, seu posicionamento desde o lugar lúdico e aparentemente irresponsável do artista-criança. Essa máscara e esse posicionamento escondem, para Palés, um ato "monstruoso" de renovação, um gesto iconoclasta. A máscara infantil do dadaísmo, para Palés 
Matos, implicaria um projeto de transgressão radical: a "queda do sistema dominante".

\subsection{A infância na poesia afro-antilhana de Palés Matos}

A experimentação poética com a infância na poesia de Palés Matos não começa, no entanto, com seu contato com o dadaísmo. Quatro anos antes, em 1918, Palés Matos tinha escrito uma série de poemas dedicados a seu filho Edgardo em um "Caderno do Bebê" que seguia o hábito norte-americano do "Baby's Book", isso é, um caderno preparado para anotar os incidentes relativos ao recém-nascido (PALÉS MATOS, 1995, p. 259). Nele, em gesto paródico, inscreveu títulos e subtítulos em inglês "Baby's parents", "Grandparents", "Born", "Place of Birth" (transcritos em espanhol na edição crítica) (PALÉS MATOS, 1995, p. 260-262). No entanto, longe da cena de plenitude e felicidade familiar tipicamente associada ao gênero do "Caderno do Bebê", Palés Matos interna-se em sentimentos de angústia, inquietação e perda nestes poemas, ligados aos eventos da trágica biografia do poeta (PALÉS MATOS, 1995, p. 261). O poema "Recién nacido/ Born" (1918), afirma:

Por desgracia, hijo mío, llegaste por noviembre cuando tu madre estaba más pálida y más débil... [...] 
Por desgracia, hijo mío, Llegaste por noviembre. (PALÉS MATOS, 1995, p. 261)

O filho, em lugar de símbolo de promessa idílica, esperança de futuridade, é associado à desgraça, à tragédia, à morte. Algo similar acontece em "Lugar de nacimiento/ Place of Birth" (1918), que afirma:

Fajardo pueblo rojo

De pasiones violentas, De hombres fuertes y secos $\mathrm{Y}$ mujeres enfermas [...]

¡Qué desgracia, hijo mío, para que tú nacieras en este pueblo rojo de pasiones violentas! (PALÉS MATOS, 1995, p. 262)

Em lugar do idílio pastoril, localista ou pitoresco, próprio da nostalgia pelo espaço do nascimento, o poema assinala o ambiente social opressivo, a violência, a doença e o imobilismo como marcos da chegada da criança ao mundo. O nascimento não é visto como origem idílica, mas como forma de assinalar a vulnerabilidade, a fragilidade da criança diante das complexidades do mundo sociopolítico e cultural de Porto Rico.

Nos poemas que logo formariam parte de seu livro Tuntún de pasa y grifería (1937), publicados em revistas 
já a partir de 1925, Palés Matos explorou a infância, em um sentido que se propunha a fundar as bases poéticas de uma cultura que incorporasse o legado da escravidão e da diáspora cultural africana à arte e à literatura das Antilhas. De fato, Palés Matos adiciona um vocabulário de termos africanos e afro-antilhanos à edição de 1950 do texto, no qual cita as mais variadas fontes sobre a cultura afro-antilhana díspares, como enciclopédias, textos literários, antropológicos, psicológicos e de viagens (VECCHINI, 1995). Por questões de espaço, neste trabalho não analisarei a totalidade dos poemas do Tuntún de pasa y grifería (1937), frequentemente mobilizados para ilustrar o papel da tradição afro-antilhana em Luis Palés Matos. Pode pensar-se, por exemplo, no título, Tuntún de pasa y grifería, no qual a primeira palavra, tuntún, refere ao ritmo do tambor, enquanto a palavra pasa e a palavra grifería referem-se ao cabelo preto, cacheado, enredado, marca da herança africana. ${ }^{3}$

No entanto, para análise da cena da infância, prefiro deter-me no poema "Falsa canción de baquiné", publicado pela primeira vez em 1929, logo em 1936 e 1937, como parte da seção "Rama" do livro Tuntún de pasa y grifería. Em "Falsa

\footnotetext{
3 Para uma leitura da relevância do mito em Palés Matos, que incorpora tanto a mitologia clássica quanto a tradição africana e o simbolismo francês e que estabelece relações significativas com o elemento musical, ver López-Baralt, 2009.
} 
canción del Baquiné", a criança negra é invocada como parte do ritual afro-antilhano. Já desde o título, o poema assinala a operação de mestiçagem, a mistura racial e cultural, dado que se refere à elaboração escrita, letrada e ficcional (falsa) do baquiné, rito próprio das religiões afro-caribenhas, dedicado à criança morta (LÓPEZ-BARALT, 1995, p. 523). Afirma o poema:

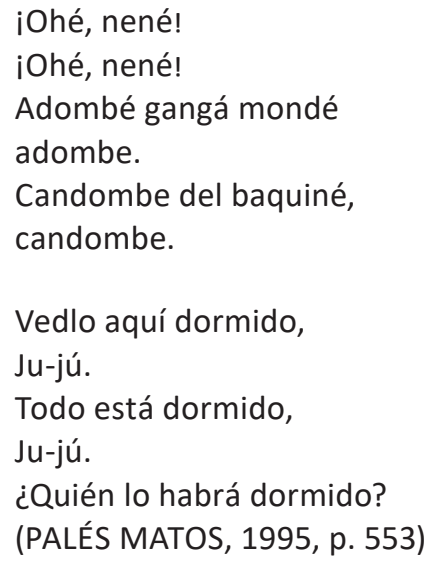

Lamento e, ao mesmo tempo, celebração, a canção invoca à criança através da tradição oral afro-antilhana, o ritmo ritualístico, a coloquialidade popular e a experimentação vanguardista com a onomatopeia, e a qualidade sonora, fônica de uma linguagem afro-antilhana. "Y a la Guinea su zombí vuelva... / - Coquí, cocó, cucú, cacá -" (PALÉS MATOS, 1995, p. 554). A criança morta empreende uma viagem ao mundo mítico, sobrenatural, africano, no qual encontra- 
se sob a assistência das divindades da religiosidade afroantilhana: "Papá Ogún, quiere mi niño, / ser un guerrero como tú; / dale gracia, dale cariño... / Papá Ogún iay! Papá Ogún" (PALÉS MATOS, 1995, p. 555). Trata-se de uma operação de transculturação entre as canções de ninar de herança hispânica e as do mundo religioso afro-antilhano, que mistura as diferentes tradições culturais. Mas vai além, dado que afirma:

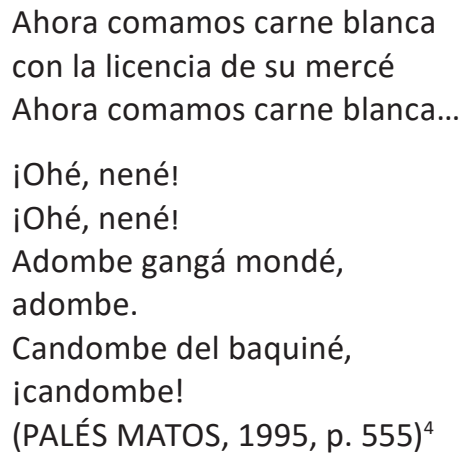

A interpelação "agora comamos carne branca", ao mesmo tempo que um grito de guerra, implica o ingresso iniciático da criança, através de uma espécie de pedagogia invertida, ao mundo oral e ritual africano, através da passagem ao mundo dos mortos. A devoração da carne branca, que a voz poética anuncia desde um lugar

\footnotetext{
4 Mercedes López Baralt, na sua edição crítica, aclara que na versão de 1929, em lugar de "Ahora comamos carne blanca" afirmava "Nos, comámonos al blanco" (PALÉS MATOS, 1995, p. 555).
} 
simuladamente serviçal, que pede "licença de sua mercê", esconde a violenta ingestão canibal do hispanismo por parte da cultura afro-antilhana, através de um ritual iniciático na cultura afro-caribenha. Desse modo, o ritual para a criança morta do baquiné anuncia uma renovação cultural, que conecta a oralidade negra, o rito afroantilhano com a palavra escrita e a cultura hispânica, na qual a criança afro-caribenha devora e incorpora ao branco e desse modo subverte as hierarquias. O baquiné revela como o Tuntún de pasa y grifería recria, em seus próprios termos, a tradição afro-antilhana, e redefine assim a cultura porto-riquenha já não exclusivamente em relação com o hispânico, mas também como uma dinâmica entre culturas, que valoriza o afro-antilhano e questiona os racismos e os códigos eurocêntricos. ${ }^{5}$

\subsection{A infância na prosa autobiográfica}

A infância possui lugar central em Litoral. Reseña de una vida inútil, prosa autobiográfica - "ficção de origens", como a chamou a crítica (LUNA, 2001) - que Palés Matos escreveu e reelaborou entre os anos de 1926 e 1951. O texto, publicado inicialmente em diferentes jornais porto-

5 Para uma leitura da relevância do mito em Palés Matos, que incorpora tanto a mitologia clássica quanto a tradição africana e o simbolismo francês e que estabelece relações significativas com o elemento musical, ver López-Baralt, 2009. 
riquenhos, está dividido em breves capítulos ou cenas que estruturam as lembranças. É significativo o fato de que na publicação de 1926 levava o título de Memorias de un hombre insignificante. Tanto nesse título inicial quanto no definitivo, chama a atenção a ênfase na "inutilidade" ou na "insignificância" do sujeito. Litoral explora a infância através de uma linguagem psicanalítica, inundada por sensações de temor, solidão, inquietação e culpa, como sintomas de dilemas sociais, raciais, culturais e políticos ${ }^{6}$.

A investigação autoanalítica e subconsciente da infância em Litoral revela tanto o interesse pela psicanálise freudiana e pelas teorias de Jung, assim como pela investigação da cultura afro-antilhana. Já no capítulo 1, nas excursões do narrador à Biblioteca Municipal, o bibliotecário Lizardi o acusa de preferir a leitura "absurda e fantástica" da I/ha do Tesouro, de Robert Louis Stevenson, às "obras edificantes" de Samuel Smiles. Devido a isso, o chama de girino, "Serás siempre un renacuajo" (PALÉS MATOS, 1984, p. 22). Ao usar a palavra "girino", o associando a uma larva, o bibliotecário aponta para a natureza anfíbia desse sujeito infantil, na fronteira, na margem de mundos culturais diferentes. Além disso, o menino já está marcado pela inutilidade e

6 De fato, a crítica tem assinalado a marca da exploração econômica, o colonialismo, a corrupção política, a miséria e a ignorância em Litoral, as quais produziriam uma sensação de amargura e tragédia (DÍAZ QUIÑONES, 1982, p. 82-83). 
a insignificância, regido pela lógica do fantástico e da aventura presente em Stevenson, alheia à produtividade material e aos sonhos de trunfo comercial da literatura de autoajuda de Samuel Smiles.

No capítulo 2, "Imágenes de la niñez", vemos um discurso de exploração do inconsciente psicanalítico, com o tom de quem está no divã e se adentra na exploração da memória subjetiva da infância: "De mi niñez, sólo dos o tres imágenes fijas, congeladas en la memoria, como islas, en medio del confuso torrente de recuerdos, incoordinables y elusivos. Aquí van... Veo, en cama con rodapié de encaje, un cuerpo rígido vestido de negro" (PALÉS MATOS, 1984, p. 22).

Note-se a comparação entre as memórias da infância e as ilhas, que apontam ao paralelo entre a cena da infância e a cultura antilhana. Relata então uma série de recordações da infância, nas quais combina-se o misterioso, o horror à morte, a violência e o desconhecido. Em primeiro lugar, narra a visão do corpo do avô morto; em segundo lugar, a ameaça de morte de uns ladrões na beira do rio; em terceiro, a fantasia paranoica infantil de ter assassinado a uma mulher cujo corpo foi encontrado esfaqueado na beira do rio. Finalmente, a fascinação da criança, ao mesmo tempo horrorizada e prazerosa, com o monstruoso 
no carnaval. O menino participa, cheio de fascinação, de uma celebração popular na qual um grupo de pessoas vai, em procissão, atrás de um "vejigante", figura mascarada pertencente ao folclore porto-riquenho. A descrição do mostro possui conotações fálicas próprias da cultura popular e carnavalesca afro-antilhana "Con monstruosa cabeza de toro, pintada de verde, de la que brotan dos cuernos enormes" (PALÉS MATOS, 1984, p. 28).

O ritual consiste em uma série de idas e vindes, perguntas e respostas entre o monstro e as crianças: "iAy tun, tuneco!" "¡Huevo de tigre!" "Este vejigante es nuevo!" exclama o vejigante, "iGüeee, tí!" "iLo conozco por los güebos!", respondem as crianças, "iLe conozco por los testículos!", repete um adulto (PALÉS MATOS, 1984, p. 28). No narrador, esse rito da festividade popular provoca um sentimento ambíguo, entre grotesco e trágico, simultaneamente horror e fascinação. A criança em Litoral está imersa em sensações de medo, desespero, angústia, sensualidade e prazer: medos e fantasias violentas e eróticas do mundo infantil. "Me pierdo en esta fútil evocación de episodios pueriles, por la influencia decisiva que tienen sobre mi carácter" (PALÉS MATOS, 1984, p. 28). Litoral explora a percepção infantil da morte, o prazer, o horror, como marcas na vida do adulto, chaves 
da subjetividade: "Como se ve, el sentido caricatural de lo grotesco y lo ridículo y un borroso e inexplicable sentimiento de culpa y persecución, marcaron desde el comienzo, mi vacilante paso por el mundo. Bajo tales auspicios ¿qué podía esperarse de mí?" (PALÉS MATOS, 1984, p. 28). A infância não se associa à inocência, mas ao ridículo, ao grotesco, à culpa e à perseguição: não há inocência possível porque o inconsciente infantil já está inundado pela angústia. Trata-se de uma subjetividade escindida.

Essa ambiguidade da percepção da criança pode ser lida como uma sorte de denúncia diante do meio social corrupto e amargo, caracterizado pelo imobilismo, pela dependência política e a exploração econômica próprias do mundo colonial e pós-colonial (DÍAZ QUIÑONES, 1965) ${ }^{7}$. Posteriormente, o narrador, morto o pai, tentaria infrutiferamente conseguir trabalho para sustentar a família, momento em que o imobilismo social se revelaria de modo ainda mais urgente na experiência do narrador.

Proponho que existem duas cenas fundamentais da infância em Litoral, que coincidem com as duas tradições culturais que, para o autor, compõem a cultura antilhana: a espanhola e a africana. O crítico Noel Luna observou

7 Arcadio Díaz Quiñones analisou a relação entre o contexto sociopolítico de Puerto Rico e a poesia afro-antilhana de Palés Matos (1982). 
a presença de duas genealogias na obra do autor: uma relacionada ao pai, e seu mundo branco, letrado, maçom e hispânico, e outra genealogia ligada ao materno, à cultura africana, à coloquialidade, ao ritual e às tradições populares negras (LUNA, 2001, p. 78). Interessa aprofundar a segunda genealogia aqui, representada por Lupe, empregada da família, de origem africana, a qual desempenha tarefas domésticas e cuida das crianças, do narrador e do irmão. Lupe é quem inicia o narrador, quando criança, na cultura afro-antilhana:

Las viejas narraciones de Lupe, entreveradas de ritos mágicos, palabras incomprensibles, - mi institución infantil las atendía perfectamente - e invocaciones misteriosas, había creado en mi mente de niño un orbe fascinante de hechicería y encantamiento. Eran los cuentos del caimán y la luna; las deliciosas fábulas negras en donde bestias y árboles lucen cualidades humanas [...]. Tarde o temprano, en aquellas narraciones aparecía el niño desobediente extraviado en la selva. (PALÉS MATOS, 1984, p. 87)

Através da narração de Lupe, o narrador (e com ele, o leitor) adentra-se no mundo mágico, incompreensível, misterioso, de feitiço e encantamento da cultura africana. Os contos africanos, as "fabulas negras" estimulam à criança a encontrar sua própria sua subjetividade negra, Ihe trazem 
sua herança africana. Assim, o menino encontra o próprio eu desdobrado na criança desobediente da narrativa, perdida na floresta. O menino que escuta experimenta, de forma vicária, a aventura que Lupe narra: os bruxos canibais perseguem à criança até que os cães o salvam. 0 canto rítmico de Lupe reproduz alternativamente as vozes graves dos bruxos “Adombe, gangá mondé, Adombe. / Adombe, gangá mondé, Adombe.", e as vozes suaves do menino que pede ajuda: “Dendifó, Carígatagre, Negombe, / ¡Sirinanaaá...!", “Alí, cotalí, suiií, / Alí, cotalí sapaaá” (PALÉS MATOS, 1984, p. 87). A criança fica horrorizada e fascinada pelo relato, que o inicia nas raízes culturais africanas, através dos sons, as músicas e o simbolismo mágico. A criança aprende o canto oral e rítmico e se torna eco das vozes dos personagens. O conto escuro, seu ritmo violento e sua linguagem oral, ritual, é percebida pelo sujeito com fascínio, como uma iniciação à cultura afro-antilhana.

¿Puede haber cuento más bello para arrullar la infancia? (Vieja, buena e inolvidable Lupe, con el espíritu - zombí o muñanga desencarnado, vuelto ya a los bosques de tu remota Guinea originaria, icuántas veces me quedé dormido en tu regazo al rumor de ese canto maravilloso, de aquel adombe profundo que todavía suena en mi corazón!)". (PALÉS MATOS, 1984, p. 87) 
A infância afro-antilhana fica condensada na imagem de Lupe, emblema da África e das suas tradições culturais. Sua figura enigmática, seus relatos, suas músicas, iniciam ao sujeito na memória afro-antilhana, reconhecendo sua herança. Lupe é vista com nostalgia, com ternura e fascínio, como facilitadora da iniciação da criança na tradição africana. Trata-se de uma reeducação do eu no marco de uma herança religiosa, poética, étnica e ritual africana.

Finalmente, o capítulo "Baquiné", narra uma viagem ao mundo afro-antilhano, mundo ritual, de religiosidade que implica também uma viagem à memória subjetiva e uma iniciação à própria herança cultural. Lupe convida ao narrador e seu irmão adultos a um baquiné, ritual dedicado à criança morta nas religiões afro-antilhanas, que se celebrará nas barracas de uma fazenda pertencente à usina açucareira Bustamante. De fato, a central açucareira é essencial para a vida do sujeito, marcando o ritmo da cidade de Guayama, na qual vive o narrador. O baquiné terá lugar como uma cerimônia noturna e clandestina oficiada pelo "Gran Ciempiés", sacerdote desse tipo de ritual na cultura AfroAntilhana (PALÉS MATOS, 1984, p. 88). Como convidado, o narrador é um estrangeiro, alheio ao ritual. Ao chegar ao lugar, o narrador observa aos participantes ataviados de 
forma solene, excitados, prontos para a celebração: "Nos sentimos como en otro mundo: el mundo de los negros. Pringa el aire un vaho de orín y lodo y a lo lejos, entre las sombras, croan las ranas. Por todas partes hierven, rebullen los negros en sus mejores prendas. - Parecen gatos con valeriana - apunta Andrés..." (PALÉS MATOS, 1984, p. 89).

O narrador sente estranheza e distância diante dos odores, dos sons e da presença das populações afroantilhanas. Lupe atua como guia e tradutora e explica o significado do ritual. Os participantes encontram-se próximos ao corpo imóvel do menino morto, enquanto o narrador permanece olhando de fora, ocupando desse modo o lugar de um espectador externo.

Lá se encontra a criança morta, em cuja homenagem realiza-se a cerimônia: "Sólo es visible el rostro, como un goterón de tinta caído en toda aquella blancura" (PALÉS MATOS, 1984, p. 89). Lupe narra a medicina e o ritual em relação à saúde da criança na cultura afro-antilhana:

Murió de brujería. No valieron ni la verdolaga, ni los teses de llantén y curía, ni los sobos de aceite de culebra con yerba bruja. Tenía el enfundio muy adentro. Se le dio el calalú de quingombó; ayunó siete días para la "limpieza" de cañafístola y naíta, mi niño. El mal espíritu estaba bien agarrao a la entretela y no quiso salir. (PALÉS MATOS, 1984, p. 90) 
Nessa explicação da morte da criança, Lupe combina - espanhol com a religiosidade e a língua africanas, apontando às práticas misteriosas, sagradas, do cuidado curativo da criança.

O ritual, dirigido pelo Gran Ciempiés, o "mestre Balestier", mistura orações cristãs e músicas da cultura popular africana. A cerimônia dura durante toda a noite, e finaliza com o canto em "cangá", "canto terrível, magnífico", do qual participam só as pessoas mais idosas: "iAdombe, gangá mondé, Adombe!". O narrador reconhece nesse canto a canção infantil que Lupe cantava para ele quando criança e se une a ela em um gesto de cumplicidade:

Estoy estupefacto. Es la misma canción infantil conque Lupe nos dormía. Y allí está ella cantándola otra vez. Andrés y yo no podemos reprimir la emoción que nos trae como una ráfaga de nuestra niñez y desde la puerta, ante el asombro de todos, rompemos a cantar también. Lupe nos oye, se vuelve y nos sonríe, con su blanca y ancha sonrisa de leche de coco. (PALÉS MATOS, 1984, p. 92)

A memória da infância provoca um encontro e um reconhecimento mútuo entre eles e Lupe, de proximidade e união, que se opõe à atitude anterior de distância e estranhamento. A infância resulta reatualizada, de tal forma que lhes permite ir além do papel do espectador e participar 
da experiência do ritual. A atualização do canto infantil "¡Adombe, gangá mondé..." Ihes permite se reapropriar da cultura afro-antilhana, acessar a genealogia africana representada por Lupe. A infância funciona como modalidade de criação e recriação de uma herança cultural represada, ou tornada invisível pelas hierarquias sociais. A infância é chave do autodescobrimento, revelando o componente afroantilhano e materno na subjetividade do narrador.

Importante dizer que o ritual sucede nos bairros do proletariado da indústria açucareira, longe da malha urbana católica, habitados por populações de ascendência africana (LÓPEZ-BARALT, 2009, p. 55). Nessas áreas houve, no século XIX, assentamentos de escravos e negros livres e, segundo Mercedes López-Baralt, lá teriam ocorrido as últimas sublevações de escravos (LÓPEZ-BARALT, 2009, p. 55). Assim, o ritual do baquiné remete à herança do sistema escravocrata nas populações afro-antilhanas. Ao longo de Litoral, de fato, há vários testemunhos da escravidão e da vida na fazenda, canções que contam a vida dos escravos e versos "negros" que falam sobre o trabalho na safra açucareira (Palés Matos, 1984, p. 97).

A cena da infância em Palés Matos aponta para a memória cultural afro-antilhana, assinalando uma história cultural de conflitos e resistências. A criança está imersa em sensações 
de terror, prazer, sensualidade, morte: empreende uma exploração do inconsciente, ao mesmo tempo que aponta para uma experiência de perda cultural e territorial, constitutiva do sujeito diaspórico afro-antilhano. Em Litoral, assim como na poesia de Luis Palés Matos, a infância constitui ponto de encontro de questões estéticas e políticas: de transgressão da língua de prestígio e dos cânones, por um lado, e da emergência de dilemas sociais e raciais, por outro. Em seus múltiplos níveis estético-políticos, a infância em Luis Palés Matos revela o legado cultural da tradição africana nas Antilhas.

\section{Referências}

BOSI, Alfredo. La parábola de las vanguardias latinoamericanas. In: SCHWARZ, Jorge. Las vanguardias latinoamericanas. Textos programáticos y textos críticos. México, FCE, p. 2-40, 2002.

CAROTTO, Francesco. Children and artist. Is a dialogue possible? In: FRANCIOLLI, Marco (Ed.). Les Enfants Terribles. The Language of Childhood in Art. Milano: Silvana Editoriale, p. 534-555, 2004. DÍAZ QUIÑONES, Arcadio. Jongos: Bodies and Spirits. In: MEIRA MONTEIRO, Pedro; STONE, Michael (Eds.). Cangoma Callling: Spirits and Rhythms of Freedom in Brazilian Jongo Slavery Songs. Dartmouth: $U$ Mass., p. 24-46, 2012.

DÍAZ QUIÑONES, Arcadio. Testimonio autobiográfico de Luis Palés Matos. Revista del Instituto de Cultura Puertorriqueña, ano. 7, n. 26, p. 1-10, 1965. DÍAZ QUIÑONES, Arcadio. La poesía negrista de Luis Palés Matos. Realidad y conciencia de su dimensión colectiva. In: El Almuerzo en la hierba. Rio Piedras: Ed. Huracán, p. 120-140, 1982.

DÍAZ QUIÑONES, Arcadio, La memoria rota. Río Piedras, Ediciones Huracán, 1993. 
FOSTER, Hal. Compulsive Beauty. Cambridge, Mass: MIT Press, 1993. IANONE, Giovanni. The Gifted Child. In: FRANCIOLLI, Marco (Ed.). Les Enfants Terribles. The Language of Childhood in Art. Milano: Silvana Editoriale, p. 500-521, 2004.

JOSIOWICZ, A. La cruzada de los niños. Infancia y cultura en América Latina (1880-1980). Tese (Doutorado em Filosofia) - Princeton University / Spanish and Portuguese Languages and Cultures Department, Princeton, 2013. Disponível em: https://dataspace.princeton.edu/handle/88435/ dsp01s7526c48x. Acesso em: 20 abr. 2021.

JOSIOWICZ, Alejandra. Por uma política da estética em Mário de Andrade: Expressionismo e Infância. Sociologia \& Antropologia. Vol. 5. p. 799-823, 2015. Disponível em: https://doi.org/10.1590/223838752015v537. Acesso em: 20 abr. 2021.

JOSIOWICZ, Alejandra. Voz e memória cultural em Litoral: Reseña de una vida inútil (1926-1959), de Luis Palés Matos. Revista do Instituto de Estudos Brasileiros. n. 63, p. 67-85, 2016. Disponível em: https:// doi.org/10.11606/issn.2316-901X.v0i63p67-85. Acesso em: 20 abr. 2021.

JOSIOWICZ, Alejandra. Luis Palés Matos. Biblioteca Virtual do Pensamento Social, 2017. Disponível em: https://bvps.fiocruz.br/vhl/ interpretes/. Acesso em: 20 de abr. 2021.

JOSIOWICZ, A. La infancia rural en César Vallejo: renovación cultural y crítica social. Artelogie, v. 14, 2019. Disponível em: https://doi. org/10.4000/artelogie.4020. Acesso em: 20 abr. 2021.

KRAUSS, Rosalind The Originality of Avant-garde and Other Modernist Myths. Cambridge: MIT Press, 1988.

LÓPEZ-BARALT, Mercedes. El extraño caso de un canon marginal: La poesía de Luis Palés Matos. In: MATOS, Luis Palés. La poesía de Luis Palés Matos. (Ed. Crítica de Mercedes López Baralt) San Juan: Ed. De la Universidad de Puerto Rico, p. 130-145, 1995.

LÓPEZ-BARALT, Mercedes. Orfeo mulato: Palés ante el umbral de lo sagrado. San Juan: La Editorial, Universidad de Puerto Rico, 2009. 
LUNA, Noel. La Ú profunda: Eros, Tradición y lengua materna en la poesía de Luis Palés Matos. Tese (Doutorado) - Princeton University / Spanish and Portuguese Languages and Cultures Department, Princeton, 2001. MYERS, Jorge. Uma "atlantic history" avant la lettre. Transculturações atlânticas e caribenhas em fernando ortiz. Sociologia \& Antropologia, v. 5, n. 3, p. 745-770, 2015. Disponível em: http://www.scielo.br/scielo. php?script=sci_arttext\&pid=S2238-38752015000300745\&lng=es\&nrm=iso. Acesso em: 20 abr. 2021.

ORTIZ, Fernando. Ni racismos ni xenofobias. Revista Bimestre Cubana, v. XXIV, n. 1, La Habana, enero-febrero de 1929, p. 6-19.

PALÉS MATOS, Luis. Obras (1914-1959). Río Piedras: Editorial de la Universidad de Puerto Rico, 1984.

PALÉS MATOS, Luis. La poesía de Luis Palés Matos. (Ed. crítica de Mercedes López Baralt) San Juan: La ed. UPR, 1995.

RANCIÈRE, Jacques. Aisthesis. Scenes from the Aesthetic Regime of Art. NY: Verso, 2013.

RODRÍGUEZ VECCHINI, Hugo, La biblioteca negra de Palés. Nómada, 2. San Juan, p. 49-59, outubro de 1995.

QUINTERO RIVERA, Mareia. La moderna tradición del mestizaje: crítica musical e idea de nación en el Caribe hispano y Brasil (1920-1940). Op.Cit. n. 16, p. 221-250, 2005. Disponível em: https://revistas.upr.edu/ index.php/opcit/article/view/929. Acesso em: 20 abr. 2021.

QUINTERO RIVERA, Mareia A cor e o som da nação: A ideia de mestiçagem na crítica musical do Caribe Hispânico e do Brasil (19281948). São Paulo: Annablume, 2000.

VECCHINI, Hugo Rodríguez. La biblioteca negra de Palés. Nómada, San Juan, v. 2. p. 49-59, 1995.

WITTMAN, Barbara. Art criticism scribbled. In: FRANCIOLLI, Marco (Ed.). Les Enfants Terribles. The Language of Childhood in Art. Milano: Silvana Editoriale, p. 567-598, 2004. 


\section{Alejandra Judith Josiowicz}

Pós-doutora pelo Centro de Pesquisa e Documentação de História Contemporânea do Brasil (FGV-CPDOC) com bolsa PNPD-Capes.

É Professora Adjunta no Departamentos de Letras Neolatinas (LNEO) do Instituto de Letras (ILE) da Universidade Estadual de Rio de Janeiro (UERJ). Participa de grupos de pesquisa sobre infância e literatura infantil, incluindo a Rede de Estudos de História das Infâncias (REHIAL), e do Núcleo de Estudos em Literatura Infantojuvenil da UERJ - NELIJ-UERJ. Publicou La cruzada de los niños. Intelectuales, infancia y modernidad literária en América Latina, na Editorial Universidad Nacional de Quilmes, assim como artigos em múltiplas revistas acadêmicas nacionais e internacionais, como Journal of Lusophone Studies, Revista IberoAmericana e Hispamérica.

Email: alejandra.josiowicz@gmail.com

Site: http://sites.google.com/view/alejandra-josiowicz/home

Lattes: https://lattes.cnpq.br/5755463684001653

ORCID iD: https://orcid.org/0000-0002-3525-1833 